\title{
Fingerprinting and genetic variability in cork oak (Quercus suber L.) elite trees using ISSR and SSR markers
}

\author{
Aimara LóPEZ-AlJoRnA ${ }^{\mathrm{a}}$, María Ángeles BUENo ${ }^{\mathrm{a} *}$, Itziar AGUINAGALDE ${ }^{\mathrm{b}}$, Juan Pedro MARTín $^{\mathrm{b}}$ \\ a INIA-CIFOR, Lab. Biotecnología Forestal, Ctra. de La Coruña km 7.5, 28040 Madrid, Spain \\ ${ }^{\mathrm{b}}$ Departamento de Biología Vegetal, Escuela Técnica Superior de Ingenieros Agrónomos, Universidad Politécnica de Madrid, \\ Ciudad Universitaria s/n, 28040 Madrid, Spain
}

(Received 22 June 2006; accepted 13 March 2007)

\begin{abstract}
Quercus suber L., is a socially, economically and ecologically important forest species in rural areas of the Mediterranean basin. Fifty three elite-trees from nine stands of four provenance regions in the Community of Extremadura (Spain) were analysed with the aim to establish their DNA-fingerprinting and the genetic relationships among them. Two types of molecular markers, microsatellites and intermicrosatellites, were used for tree genotyping. Microsatellite markers could distinguish $94 \%$ of the trees. Observed and expected heterozygosities, and effective number of alleles were correlated with the polymorphism information content (PIC). Intermicrosatellite patterns were used to construct a dendrogram. They showed high levels of genetic diversity in these elite trees, without any clear relationship with provenance regions. Both types of markers detected a high level of intra-stand variability, which is common in Quercus species, probably due to its mating system, the low distance among stands and the small size of stands. Others factors that could affect this result, such as introgression between $Q$. suber L. and $Q$. ilex L., are also commented. The high level of genetic variability detected in these elite trees can be useful for improvement programs. Also the usefulness of SSR and ISSR markers to establish the DNA-fingerprinting of each tree could be focused to select clonal lines of commercial interest.
\end{abstract}

Quercus suber / cork oak / elite trees / DNA-fingerprinting / PCR markers

Résumé - Empreintes génétiques et étude de la variabilité génétique d'arbres élites de chêne-liège (Quercus suber L.) sur base de marqueurs ISSR et SSR. Quercus suber L. est une espèce forestière d'importance économique, sociale, et écologique dans les zones rurales du bassin méditerranéen. Cinquante-trois arbres élites issus de neuf peuplements situés dans quatre régions de provenance dans la Communauté d’Extremadure (Espagne) ont été analysés afin de révéler leurs empreintes génétiques et d'établir les possibles relations génétiques entre eux. Nous avons utilisé deux types de marqueurs moléculaires : microsatellites et intermicrosatellites. Les microsatellites ont permis de distinguer $94 \%$ des arbres. Les niveaux d'hétérozygotie observés et attendus, ainsi que les nombres effectifs d'allèles ont été corrélés avec les valeurs du contenu d'information de polymorphisme (PIC). Les résultats des intermicrosatellites ont été utilisés pour construire un dendrogramme. Ils ont révélé la présence d'une diversité génétique élevée au sein des arbres élites, bien qu'il n'y ait pas de relation claire avec les régions de provenance. Les deux types de marqueurs utilisés ont également révélé une grande variabilité génétique à l'intérieur de chacun des peuplements. Ceci est courant chez les espèces de Quercus et résulte probablement de leur mode de reproduction, de la distance faible entre les peuplements et de la petite taille des peuplements. D'autres facteurs pouvant affecter ces résultats, comme l'introgression entre $Q$. suber L. et $Q$. ilex L., sont commentés. La grande variabilité génétique détectée parmi ces arbres élites peut être d'une grande utilité pour les programmes d'amélioration. D'autre part, la capacité des marqueurs SSR et ISSR pour établir l'empreinte génétique de chaque arbre pourrait être utilisée pour sélectionner des lignées clonales d'intérêt commercial.

Quercus suber / chêne-liège / arbres élite / empreintes génétiques / marqueurs PCR

\section{INTRODUCTION}

Cork oak (Quercus suber L.) is one of the most important forest species growing in semi-arid regions of southern Europe, because of its distinctive properties. Ecologically it serves as an environmental protector, stabilising the marginal areas. Besides it is commercially important because of the increasing demand of cork in the recent years. In the society it generates employment among the populations of marginal areas along the Mediterranean basin, contributing to the maintenance and the enrichment of the rural populations.

In short, a deeper knowledge and optimisation in the management of these semi-arid environments might produce great

*Corresponding author: bueno@inia.es benefits in southern Europe Peninsulas [16]. Most of these stands are old and they need a more efficient management for sustainable development. At present the reforestation or the rejuvenation of these areas is stimulated by the national governments and by the European Commission [17]. Nevertheless, to replant in an efficient way it needs the selection of trees that produce quality seeds for its viability, vigour and resistance to diseases. To advance in the selection of "elite" trees, their molecular characterisation appears as an excellent approach, which together genecological studies $[38,40]$ might mean in the near future towards the optimisation of these genetic resources in support of reforestation and cork production.

The identification of forests of cork oak needing urgent conservation is important in the Mediterranean 
Table I. Stands, provenance regions, location and number of individuals of Quercus suber L. analysed.

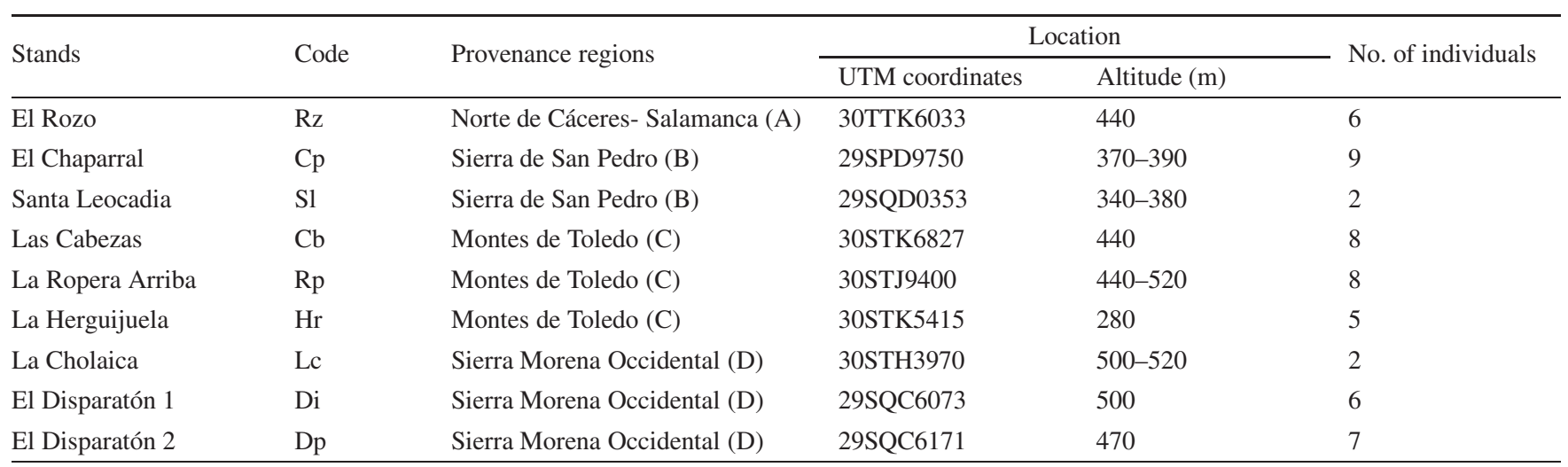

Basin, which belong to the Biodiversity Hotspots (http://www.biodiversityhotspots.org). Also, The WWF launched a 5-year programme in July 2004, to protect, manage and restore the natural wealth of cork oak landscapes by influencing the policies, practices and markets that affect them (http://assets.panda.org/downloads/factsheetcork.pdf). Recently, the international Forest Stewardship Council (http://www.fsc.org) announced the first certification of cork oak forest, which supports its environment friendly, socially beneficial and economically feasible management.

Selected clonal lines obtained with these elite trees, could enter in the CNMB ("Catalogo Nacional de Materiales de Base", National Catalogue of Basic Materials), which catalogues these selected materials to be used in forest management.

In the Iberian Peninsula cork oak is mainly used for manufacture of bottle stoppers, which is indispensable to the wine industry. In Spain, the total cork production in 2001 was estimated to be $57581 \mathrm{Tm}$, being the Community of Extremadura the second largest cork producing zone [23]. This zone also produces one of the best quality cork (thickness and porosity).

The probability of improving the quality of cork/trees by the traditional methods is very low because most traits show multiple gene inheritance. In an effort to obtain trees adapted to the ecological conditions and with a high productivity and good quality cork, elite trees from the Community of Extremadura have been selected to be used in breeding programs through tissue culture $[7,8,32]$. These trees have large and straight trunk, and they are disease free.

Since the elite individuals come from four provenance regions, with known geographical differentiation and ecological variations, it is important an accurate identification and to determine the genetic relationship among these elite trees. The availability of molecular markers like microsatellites (SSR) and intermicrosatellites (ISSR) is likely to provide more specific genetic information due to the high number of polymorphic loci that can be obtained $[12,25]$. SSR markers have been developed in different species of Quercus genera $[12,24,28,41]$, and their transferability to $Q$. suber was previously tested [20-22]. ISSR technique initially developed by Zietkiewicz et al. [46], allows to obtain molecular markers amplified by PCR in the presence of one primer complementary to a target microsatellite, and has been widely tested in many plants families [5]. Nevertheless, this technique has not been tested yet in Quercus species.

In the present study, both types of molecular markers have been used to establish the fingerprint of the selected elite-trees and to determine their genetic relationship. This was done within the context of a breeding programme aimed at obtain clonal lines with commercial interest.

\section{MATERIAL AND METHODS}

\subsection{Plant material and DNA extraction}

Fifty three trees from nine selected stands located into four provenance regions in Spain [10] were analysed (Tab. I). The cork oaks used in this study were selected in the framework of a national project (AGL 2000-0029-P4-3) based on both their cork quality and high productivity. Mature leaves were collected between August 2002 and June 2003, and stored at $-20{ }^{\circ} \mathrm{C}$ until DNA extraction.

DNA was extracted following Doyle and Doyle [14], and was quantified comparing band intensities with know standards of lambda DNA on $1 \%$ agarose gels. Working solution of DNA $(10 \mathrm{ng} / \mu \mathrm{L})$ was made with sterile double-distilled water.

\subsection{SSR-PCR}

Three primer pairs (ssrQpZAG15, ssrQpZAG46 and ssrQpZAG110), designed by Quercus petraea (Matt.) Liebl. [41], were used to amplify microsatellite loci (AG)n repeats. Previous studies demonstrated their Mendelian inheritance, as well as their transferability among different Quercus species [20-22, 39, 42]. Primer pairs were synthesized from published sequences, and one of the primers of each pair was fluorescently labelled with a fluorophore, 6-FAM (blue), TET (green) or HEX (yellow).

PCR reactions were performed in $25 \mu \mathrm{L}$ of final volume containing $10 \mathrm{mM}$ Tris- $\mathrm{HCl}$ ( $\mathrm{pH} 9.0$ ), $50 \mathrm{mM} \mathrm{KCl,} 2 \mathrm{mM} \mathrm{MgCl}_{2}$, $200 \mu \mathrm{M}$ of each dNTP, $0.2 \mu \mathrm{M}$ of forward and reverse primers, $0.5 \mathrm{U}$ of Taq-DNA polymerase (ECOGEN, S.R.L.), and $20 \mathrm{ng}$ of template DNA. PCR amplifications were carried out in a PE-9600 thermal cycler (PE Applied Biosystems) following the conditions as 
Table II. ISSR primer sequences, annealing temperature, number of fragments scored and approximate size range (in base pairs) of the fragments resulted from each primer in the 53 cork oak studied. ISSR primer index (SPI) values are also indicated.

\begin{tabular}{lcccc}
\hline $\begin{array}{l}\text { Primer } \\
\text { Code }\end{array}$ & Sequence $^{\mathrm{a}}$ & $\begin{array}{c}\text { Annealing } \\
\text { temperature }\left({ }^{\circ} \mathrm{C}\right)\end{array}$ & $\begin{array}{c}\text { No. of } \\
\text { fragments scored }\end{array}$ & $\begin{array}{c}\text { Fragment } \\
\text { size range }(\mathrm{bp})\end{array}$ \\
\hline UBC811 & $(\mathrm{GA})_{8} \mathrm{C}$ & 53 & 13 & $275-1000$ \\
$\mathrm{UBC} 835$ & $(\mathrm{AG})_{8} \mathrm{YC}$ & 52 & 13 & $400-1300$ \\
UBC841 & $(\mathrm{GA})_{8} \mathrm{YC}$ & 52 & 22 & $160-1600$ \\
$\mathrm{UBC} 857$ & $(\mathrm{AC})_{8} \mathrm{YG}$ & 52 & 11 & $350-2000$ \\
$\mathrm{UBC} 878$ & $(\mathrm{GGAT})_{4}$ & 53 & 11 & $600-1600$ \\
UBC880 & $(\mathrm{GGAGA})_{3}$ & 53 & 15 & 3.36 \\
\hline
\end{tabular}

${ }^{\text {a }}$ Y stands for pyrimidine.

in Barreneche et al. [2]. Amplified products were separated in capillary electrophoresis using an semiautomatic sequencer ABI PRISM model 310 (PE Applied Biosystems). The labelled fragments were detected and sized using GENESCAN software (PE Applied Biosystems). GENESCAN-350 TAMRA (PE Applied Biosystems) was used as internal standard.

\subsection{ISSR-PCR}

Six ISSR primers were selected (see Tab. II) from previously tested 22 primers, provided in the set \#9 of the University of British Columbia Biotechnology Laboratory (UCB, Vancouver, Canada). These primers were chosen according to different criteria: clarity, number and reproducibility of amplified fragments. DNA amplifications were performed in a $20 \mu \mathrm{L}$ reaction volume containing $10 \mathrm{mM}$ Tris- $\mathrm{HCl}$ (pH 9.0), $50 \mathrm{mM} \mathrm{KCl,} 2 \mathrm{mM} \mathrm{MgCl}_{2}, 150 \mu \mathrm{M}$ of each dNTP, $0.5 \mu \mathrm{M}$ of a single ISSR primer, $0.5 \mathrm{U}$ of Taq-DNA polymerase (ECOGEN, S.R.L.), and $20 \mathrm{ng}$ of template DNA. PCR amplifications were carried out in a PTC-100 thermal cycler (MJ Research, Inc.) following the conditions described by Martín and SánchezYélamo [33]. Amplified products were separated by standard horizontal electrophoresis in $2 \%$ agarose gels, and then stained with ethidium bromide. Size of amplified fragments was estimated by reference to a $100 \mathrm{bp}$ Ladder (Pharmacia).

For ISSR as well as SSR, at least two PCR amplifications using DNA from different extractions were done for each sample. Also, with ISSR technique only reproducible bands in several runs were considered for analysis.

\subsection{Data analysis}

Because SSR-PCR are codominant markers, the allele and genotype frequencies in the sample studied can be obtained by direct counting. For each locus, the observed heterozygosity was calculated as the ratio of the number of heterozygous individuals above the total number of individuals analysed. Expected heterozygosity was calculated following Nei [34] as $H_{e}=1-\Sigma p_{i}^{2}$, where $p_{i}$ is the frequency of the $i$ th allele in the sample studied for each locus. The effective number of alleles was estimated as ENA $=1 / \Sigma p_{i}^{2}$ according to Kimura and Crow [29]. To evaluate the discrimination power of a marker locus its polymorphism information content (PIC; Botstein et al. [6]) was calculated. This is the probability that an individual will be informative of the respect to the segregation of its inherited alleles. In addition, the expected probability of identity $\left(\mathrm{P}_{I D}\right.$; probability that two individuals drawn at random from a sample will have the same genotype at multiple loci) was estimated for each locus following Waits et al. [44].

ISSR bands were interpreted as dominant markers (biallelic) and fragments were scored as present (1) or absent (0). A pair-wise similarity matrix was calculated using the Dice's coefficient [11]. This similarity matrix was employed to construct a dendrogram by the unweighted pair group method with arithmetical averages (UPGMA), using SAHN-clustering and TREE programs from the NTSYS-pc, vers. 2.02 package [37]. In addition, a polymorphic index content (PIC $=1-p^{2}-q^{2}$; Ghislain et al. [19]) was calculated, where $p$ is the frequency of a given fragment and $q$ is the frequency of its absence. This value was used to generate the ISSR primer index (SPI; Raina et al. [36]), by adding up the PIC values of the bands amplified by the same primer. Fragments showing a frequency less than 0.05 or above 0.95 were discarded because they are close to the empirical threshold for the differences detection by ISSR analysis [19].

\section{RESULTS}

\subsection{SSR analysis}

Four alleles were detected for each of both QpZAG15 and QpZAG46 loci, whereas 20 were found at QpZAG110 locus, giving a total of 28 alleles detected (Tab. III). For each of the three loci, one common allele could be identified, with a frequency of 0.68, 0.55 and 0.29 in QpZAG15, QpZAG46 and QpZAG110 loci, respectively.

Five different genotypes were observed at QpZAG15 locus, seven at QpZAG46 locus and 35 at QpZAG110 locus (Tab. III). The combination of genotypes for the three SSR loci enabled to distinguish 50 different patterns among the 53 individuals studied.

The observed heterozygosity varied between $57 \%$ (QpZAG15) and 91\% (QpZAG110), with a mean value of $72 \%$. The expected heterozygosity ranged from $47 \%$ in QpZAG15 locus to 88\% in QpZAG110 locus, with an average of $65 \%$ (Tab. III). Observed heterozygosity levels were slightly higher than the corresponding expected heterozygosity estimates for all loci.

The PIC values are slightly lower or similar to the corresponding expected heterozygosity estimates. On the other 
Table III. Allele size range (ASR), number of alleles detected (NA), number of genotypes observed (NG), effective number of alleles (ENA), observed and expected heterozygosity $\left(H_{o}\right.$ and $\left.H_{e}\right)$, polymorphism information content $(\mathrm{PIC})$, and expected probability of identity $\left(\mathrm{P}_{I D}\right)$ in the three ssrQpZAG microsatellite loci analysed on the 53 cork oak trees.

\begin{tabular}{lcccccccc}
\hline Locus & ASR & NA & NG & ENA & $H_{o}$ & $H_{e}$ & PIC & P \\
\hline QpZAG15 & $118-124$ & 4 & 5 & 1.89 & 0.57 & 0.47 & 0.41 & 0.324 \\
QpZAG46 & $186-192$ & 4 & 7 & 2.53 & 0.68 & 0.60 & 0.54 & 0.204 \\
QpZAG110 & $218-262$ & 20 & 35 & 8.05 & 0.91 & 0.88 & 0.88 & 0.016 \\
Mean & - & 9.33 & 15.67 & 4.16 & 0.72 & 0.65 & 0.61 & - \\
Cumulative & - & 28 & 50 & - & - & - & - & 0.00106 \\
\hline
\end{tabular}

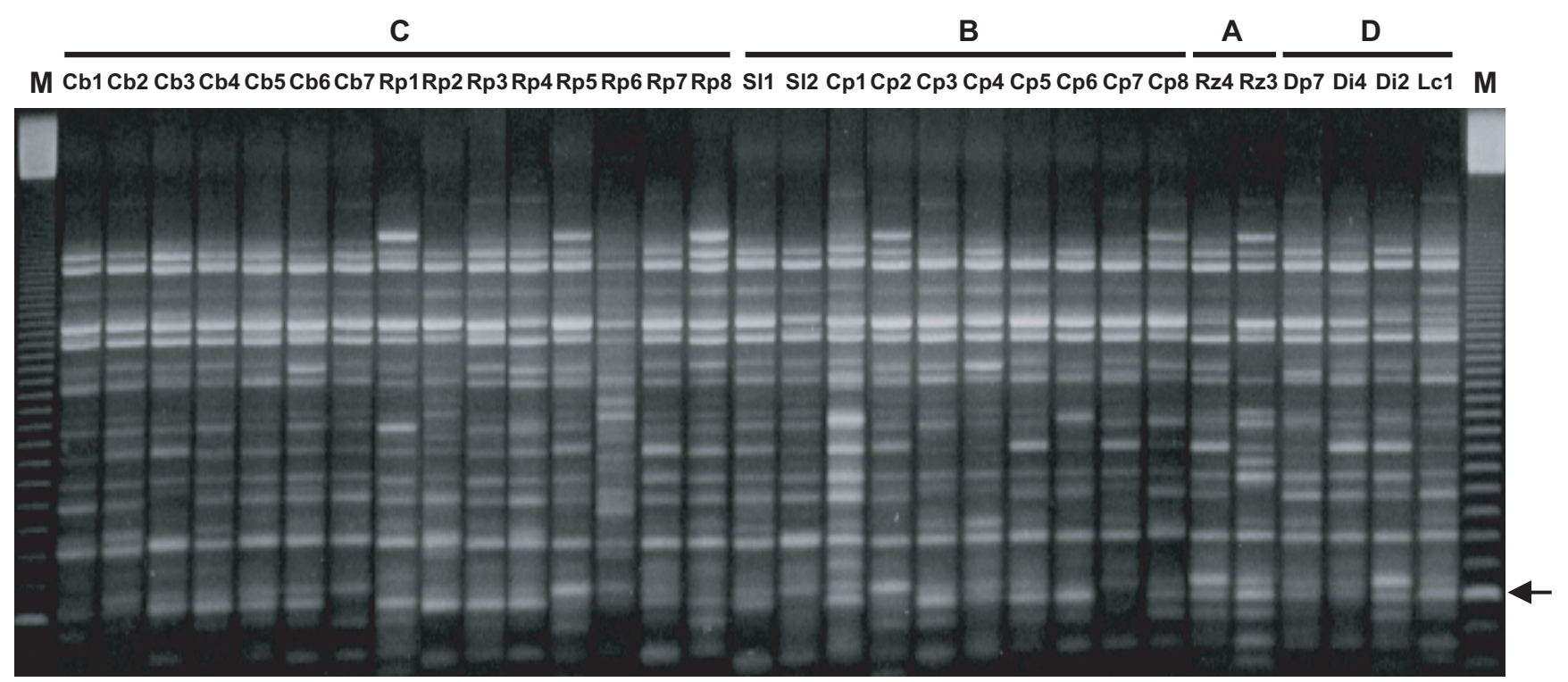

Figure 1. ISSR patterns obtained on a 2\% agarose gel for 31 individuals of Quercus suber L. using the primer UBC841. M = Molecular size marker (100-base pair Ladder, Pharmacia). Arrow indicates the 250 bp band. See Table I for sample codes: A to D - provenance regions; Rz, $\mathrm{Cp}, \mathrm{Sl}, \mathrm{Cb}, \mathrm{Rp}, \mathrm{Lc}$, Di and Dp - stands code; 1 to 8 - sample numbers for each stand.

hand, ENA values were also correlated with the corresponding PIC values (Tab. III). The most informative locus was QpZAG110, with a PIC of $88 \%$ and an effective number of alleles of 8.05. Our results indicated that these two parameters, PIC and ENA, can be used to evaluate the usefulness of different SSR markers for reliable individual distinction in cork oak.

Table III also shows the expected probability of identity $\left(\mathrm{P}_{\mathrm{ID}}\right)$ for each locus, and the cumulative value for all loci. The $\mathrm{P}_{\mathrm{ID}}$ values ranged from 0.016 in QpZAG110 locus to 0.324 in QpZAG15 locus. Considering all the three loci combined there are about one chance in 1000 that two individuals selected randomly from a sample possessing the allele and the genotype frequencies found in this study will have identical genotypes at all loci.

\subsection{ISSR analysis}

ISSR-PCR amplifications using six primers generated a total of 85 reliable fragments from the 53 individuals studied. The size of these fragments ranged between 160 and $2000 \mathrm{bp}$ (Tab. II). Seventy seven fragments $(90.6 \%)$ were polymorphic.
Figure 1 shows the amplification patterns generated using the primer UBC841 in 31 individuals of $Q$. suber. The minimum and maximum number of fragments generated per primer were 11 (primers UBC857 and UBC878) and 22 (primer UBC841), respectively (Tab. II), with an average of 14.2 fragments.

The polymorphic index content (PIC) values ranged from 0.15 to 0.50 , and the ISSR primer index (SPI) values varied from 3.26 (primer UBC857) to 5.36 (primer UBC841) (see Tab. II).

The UPGMA dendrogram obtained using the 85 ISSR fragments scored in the 53 individuals showed a high level of genetic diversity among these individuals, and this variability seems to be distributed among the different groups without any clear relationship with stand and/or provenance regions (Fig. 2).

\section{DISCUSSION}

The main objective of this study was to characterise selected elite-trees of Quercus suber using molecular markers, which would eventually help to define strategies for reforestation, maintenance of rural areas and optimisation of cork 


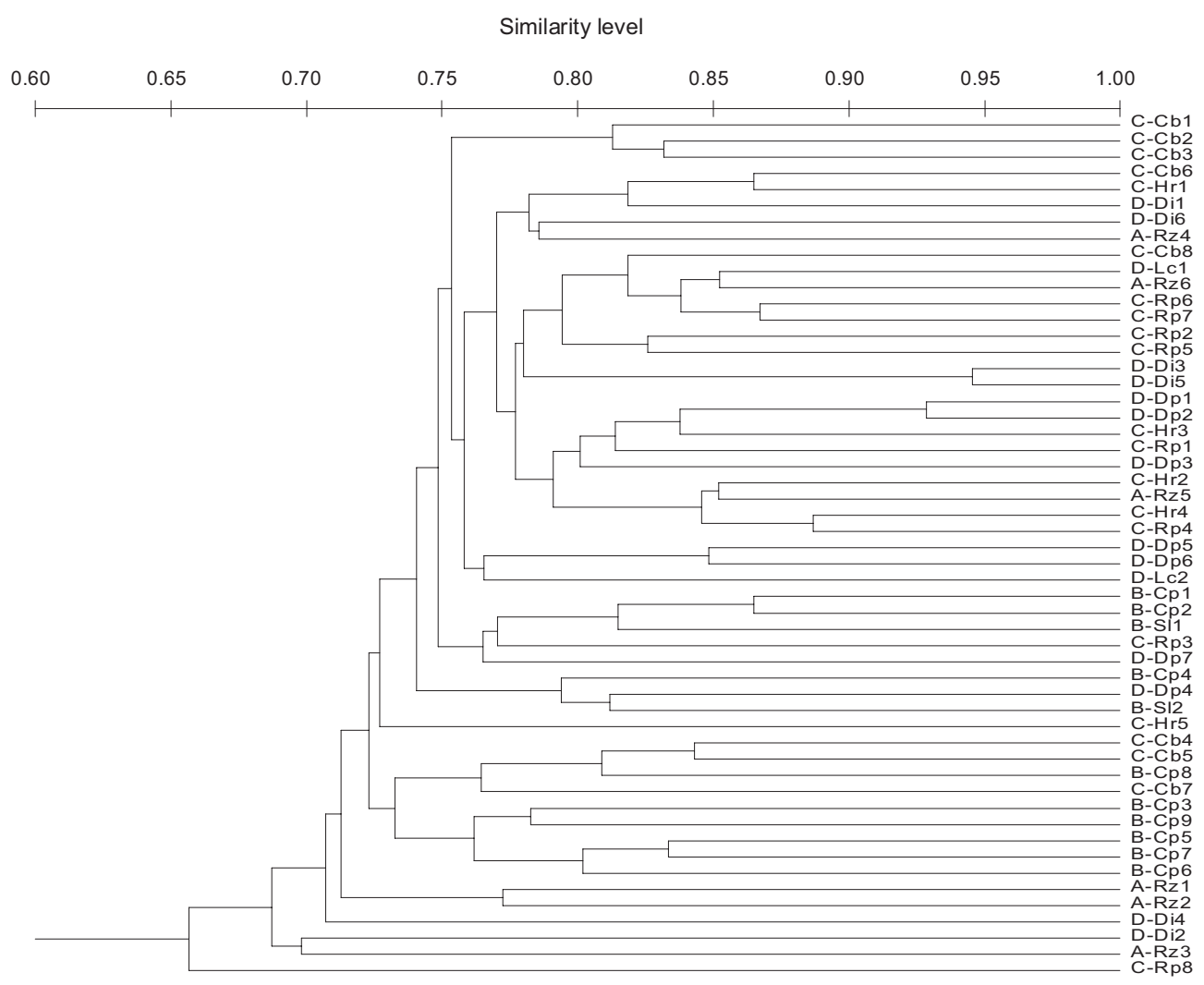

Figure 2. Dendrogram generated by UPGMA clustering analysis, using the Dice's coefficient based on 85 ISSR bands, showing the relationship among the 53 individuals of Quercus suber L. See Table I for sample codes: A to D - provenance regions; Rz, Cp, Sl, Cb, Rp, Hr, Lc, Di and Dp - stands code; 1 to 9 - sample numbers for each stand.

production. This preliminary study makes available the first molecular data of elite trees that can be applied to the management genetic resources of $Q$. suber.

The SSR and ISSR techniques proved to be useful tool to differentiate individuals as they generated a high level of polymorphic patterns. The three microsatellite loci used in our study allowed us to differentiate $94 \%$ the individual tested. Even if they were originally developed for $Q$. petraea [41], the transferability of these SSR-primers to different species of the Quercus genus was previously reported [20-22, 39, 42]. All SSR loci analysed in this study generated stable amplification fragments, even though QpZAG46 was reported as an unsuccessful locus to be transferred to $Q$. suber by Hornero et al. [22]; in our study, four alleles were detected for this locus.

Studied loci showed a common pattern, where at least one common allele was observed in each locus. The high frequency of these common alleles $(0.68,0.55$ and 0.29 in QpZAG15, QpZAG46 and QpZAG110 loci, respectively) could reflect their ancient origin [9].

The size range and number of detected alleles for QpZAG15 and QpZAG110 loci were similar to those previously found by Hornero et al. [22] in a sample of 41 cork oak trees from four Spanish stands, which were different from the nine stands selected for our study. A high number of alleles were found in the QpZAG110 locus (20), while only six and seven alleles were reported in $Q$. robur and $Q$. petraea, respectively $[30,42]$. The observed and expected heterozygosity levels also were similar to those previously obtained by Hornero et al. [22].

This is the first time that the ISSR technique has been used in a molecular characterization study of Quercus species. The higher SPI values are clearly related to a high number of fragments scored by primer. Working with Arachis hypogaea, Raina et al. [36] concluded that SPI over 1.25 are better to be used in the peanut fingerprinting generation. The SPI values in the elite trees analysed ranged from 3.26 to 5.25 (see Tab. II), implying that the selected primers are good for identification of cork oak.

Both SSR and ISSR detected a high level of intrapopulation variability. This characteristic is common to other Quercus species like $Q$. macrocarpa [12,13], $Q$. robur and $Q$. petraea [18], and it is probably due to the mating system of this genus, the low distance among stands, and the small size of stands.

Many molecular markers have been used to characterize the genetic diversity of natural populations of $Q$. suber. Using restriction fragments of chloroplast DNA (PCR-RFLP technique) and isozyme analysis of $Q$. suber populations, Jiménez [26] clustered the four provenance regions tested in this study to one group only named "Southwest", showing that the highest variability occurs within populations and the 
possible existence of a homogenising factor. Although the seed dispersal is too low to be a homogenising factor [1], paternity analysis in the Quercus species [13,35,45] demonstrate that the high level of pollen flow could influence variability within populations and contribute to decrease the inter-population variability.

There are others factors that could affect the high levels of variability found in our samples. Several studies analysing chloroplast and mitochondrial DNA [3, 26, 27, 31] as well as isozymes [15], demonstrated introgression between $Q$. suber and $Q$. ilex $\mathrm{L}$., species that share a part of their distribution area and in our stands often these species are mixed. Nevertheless, these crosses could be limited by interspecific barriers, like those described by Boavida et al. [4]; very low natural rates of crosses, and existence of unidirectional successful cross, i.e. when $Q$ ilex was used as female parent, but in the reciprocal cross does not occur. Phenological differences between $Q$. suber and $Q$. ilex also favour this asymmetric hybridisation [43].

The high genetic variability obtained in the samples indicates the advantage of these selected elite-trees in the development of breeding programs, and the usefulness of SSR and ISSR markers in breeding experiments and to establish of DNA-fingerprinting of cork oak trees. Finally, net outcome of this study (i.e. DNA-fingerprint of these trees) would be recognised by the Forest Stewardship Council and will be referred in the CNMB ("Catalogo Nacional de Materiales de Base", National Catalogue of Basic Materials).

Acknowledgements: This research was supported by grant RTA2005-00118-C2-02 from the National Program of Agrofood Technology and Resources of the Ministry and Science and Technology, and AGL 2000-0029-P4-03 from National Plan of $\mathrm{I}+\mathrm{D}+\mathrm{I}$ of the Ministry of Science and Culture. The collaboration of TRAGSA, IPROCOR and TIETAR Spanish industry, was very much appreciated. We thank Dr. A. Mohanty for an early critical reading of the paper, and to both anonymous reviewers for their comments to improve the manuscript.

\section{REFERENCES}

[1] Bacilieri R., Labbe T., Kremer A., Intraspecific genetic structure in a mixed population of Quercus petraea (Matt.) Liebl. and Q. robur L., Heredity 73 (1994) 130-141.

[2] Barreneche T., Bodenes C., Lexer C., Trontin J.F., Fluch S., Streiff R., Plomion C., Roussel G., Steinkellner H., Burg K., Favre J.M., Glössl J., Kremer A., A genetic linkage map of Quercus robur L. (pedunculate oak) based on RAPD, SCAR, microsatellite, minisatellite, isozyme and 5S rDNA markers, Theor. Appl. Genet. 97 (1998) 1090-1103.

[3] Belahbib N., Pemonge M.H., Ouassou A., Sbay H., Kremer A., Petit R.J., Frequent cytoplasmic exchanges between oaks species that are not closely related: Quercus suber and $Q$. ilex in Morocco, Mol. Ecol. 10 (2001) 2003-2012.

[4] Boavida L.C., Silva J.P., Feijó J.A., Sexual reproduction in the cork oak (Quercus suber L.). II. Crossing intra- and interspecific barriers, Sex. Plant Reprod. 14 (2001) 143-152.

[5] Bornet B., Branchard M., Nonanchored inter simple sequence repeat (ISSR) markers: reproducible and specific tools for genome fingerprinting, Plant Mol. Biol. Rep. 19 (2001) 209-215.
[6] Botstein D., White R.L., Skolnick M., Davis R.W., Construction of a genetic linkage map in man using restriction fragment length polymorphisms, Am. J. Hum. Genet. 32 (1980) 314-331.

[7] Bueno M.A., Astorga R., Manzanera J.A., Plant regeneration through somatic embryogenesis in Quercus suber, Physiol. Plant. 85 (1992) 30-34.

[8] Bueno M.A., Gómez A., Manzanera J.A., Somatic and gametic embryogenesis in Quercus suber L., in: Jain S.M., Gupta P.K., Newton R.J. (Eds.), Somatic embryogenesis in woody plants, Forestry Sciences, Vol. 67, Kluwer Academic Publishers, Dordrecht, 2000, pp. 479-508.

[9] Charlesworth B., Sniegowski P., Stephan W., The evolutionary dynamics of repetitive DNA in eukaryotes, Nature 371 (1994) 215220.

[10] Díaz-Fernández P.M., Jiménez P., Catalán G., Martín S., Gil L., Provenance regions of Quercus suber L. in Spain, ICONA, Madrid (España), 1995.

[11] Dice L.R., Measures of the amount of ecologic association between species, Ecology 26 (1945) 297-302.

[12] Dow B.D., Ashley M.V., Microsatellite analysis of seed dispersal and parentage of saplings in burk oak, Quercus macrocarpa, Mol. Ecol. 5 (1996) 615-627.

[13] Dow B.D., Ashley M.V., High levels of gene flow in bur oak revealed by paternity analysis using microsatellites, J. Hered. 89 (1998) 62-70.

[14] Doyle J.J., Doyle J.L., Isolation of DNA from fresh tissue, Focus 12 (1990) 13-15.

[15] Elena-Roselló J.A., Cabrera E., Evidence for hibridization between sympatric holm-oak and cork-oak in Spain based on diagnostic enzyme markers, Vegetatio 99-100 (1992) 115-118.

[16] EU Project FAIR5-CT97-3480, http://www.divapra.unito.it/res/eu 3480/, 1997, accessed on June 7, 2006.

[17] EU Regulation (EEC), No. 2080/92 instituting a Community aid scheme for forestry measures in agriculture (OJ L215, 30.7.1992), 1992.

[18] Finkeldey R., Genetic variation of Oaks (Quercus spp.) in Switzerland. 2. Genetics structures in "Pure" and "Mixed" forest of pedunculate oak (Q. robur L.) and sessile oak (Q. petraea (Matt.) Liebl.), Silvae Genet. 50 (2001) 22-30.

[19] Ghislain M., Zhang D., Fajardo D., Huaman Z., Hijmans R.J., Marker-assisted sampling of the cultivated Andean potato Solanum phureja collection using RAPD markers, Genet. Resour. Crop Evol. 46 (1999) 547-555.

[20] Gómez A., Pintos B., Aguiriano E., Manzanera J.A., Bueno M.A., SSR markers for Quercus suber tree identification and embryo analysis, J. Hered. 92 (2001) 292-295.

[21] Gómez A., Manzanera J.A., Alia R., Gónzalez-Martínez S., Bueno M.A., Microsatellite diversity in forest trees, in: Pandalai S.G. (Ed.), Recent Research Developments in Genetics and Breeding, Vol. 1, Part II, Research Signpost, 2004, pp. 425-448.

[22] Hornero J., Gallego F.J., Martínez I., Toribio M., Testing the conservation of Quercus spp. microsatellite in cork oak, Q. suber L., Silvae Genet. 50 (2001) 162-167.

[23] Instituto Nacional de Estadística (INE), Anuario estadístico de España, Madrid (España), 2004.

[24] Isagi Y., Suhandono S., PCR primers amplifying microsatellite loci of Quercus myrsinifolia Blume and their conversation between oak species, Mol. Ecol. 6 (1997) 897-899.

[25] Jianming G., Shougong Z., Liwang Q., Yong Z., Chunguo W., Wenqin S., ISSR and AFLP identification and genetic relationships of Chinese elite accessions from the genus Populus, Ann. For. Sci. 63 (2006) 499-506.

[26] Jiménez M.P., Análisis de la variabilidad genética de Quercus suber L. mediante marcadores moleculares y su aplicación a la conservación de recursos genéticos, Ph.D. thesis, Instituto Nacional de 
Investigación y Tecnología Agraria y Alimentaria (INIA), Madrid (España), 2001, 146 p.

[27] Jiménez P., López de Heredia U., Collada C., Lorenzo Z., Gil L., High variability of chloroplast DNA in three Mediterranean evergreen oaks indicates complex evolutionary history, Heredity 93 (2004) 510-515.

[28] Kampfer S., Lexer C., Glössl J., Steinkellner H., Characterization of $(\mathrm{GA})_{n}$ microsatellite loci from Quercus robur, Hereditas 129 (1998) 183-186.

[29] Kimura M., Crow J.F., The number of alleles that can be maintained in a finite population, Genetics 49 (1964) 725-738.

[30] Lefort F., Lally M., Thompson D., Douglas G.C., Morphological traits, microsatellite fingerprinting and genetic relatedness of a stand of elite oaks (Q. robur L.) at Tullynally, Ireland, Silvae Genet. 47 (1998) 257-262.

[31] Lumaret R., Mir C., Michaud H., Raynal V., Phylogeographical variation of chloroplast DNA in holm oak (Quercus ilex L.), Mol. Ecol. 11 (2002) 2327-2336.

[32] Manzanera J.A., Astorga R., Bueno M.A., Somatic embryo induction and germination in Quercus suber L., Silvae Genet. 42 (1993) 90-93.

[33] Martín J.P., Sánchez-Yélamo M.D., Genetic relationships among species of the genus Diplotaxis (Brassicaceae) using inter-simple sequence repeat markers, Theor. Appl. Genet. 101 (2000) 1234 1241.

[34] Nei M., Molecular evolutionary genetics, Columbia University Press, New York, 1987.

[35] Petit R.J., Kremer A., Wagner D.B., Geographic structure of chloroplast DNA polymorphisms in European oaks, Theor. Appl. Genet. 87 (1993) 122-127.

[36] Raina S.N., Rani V., Kojima T., Ogihara Y., Singh K.P., Devarumath R.M., RAPD and ISSR fingerprints as useful genetic markers for analysis of genetic diversity, varietal identification, and phylogenetic relationships in peanut (Arachis hypogaea) cultivars and wild species, Genome 44 (2001) 763-772.
[37] Rohlf F.J., NTSYS-pc: Numerical taxonomy and multivariate analysis system, Version 2.02, Exeter Publications Setauket, New York, 1998.

[38] Skot L., Hamilton N.R.S., Mizen S., Chorlton K.H., Thomas I.D., Molecular genecology of temperature response in Lolium perenne: 2. association of AFLP markers with ecogeography, Mol. Ecol. 11 (2002) 1865-1876.

[39] Soto A., Lorenzo Z., Gil L., Nuclear microsatellite markers for the identification of $Q$. ilex $\mathrm{L}$. and $Q$. suber L., hybrids, Silvae Genet. 52 (2003) 63-66.

[40] St Clair J.B., Mandel N.L., Vance-Boland K.W., Genecology of Douglas fir in western Oregon and Washington, Ann. Bot. 96 (2005) 1199-1214.

[41] Steinkellner H., Fluch S., Turetschek E., Lexer C., Streiff R., Kremer A., Burg K., Glössl J., Identification and characterization of (GA/CT)n - microsatellite loci from Quercus petraea, Plant Mol. Biol. 33 (1997) 1093-1096.

[42] Steinkellner H., Lexer C., Turetschek E., Glössl J., Conservation of (GA)n microsatellite loci between Quercus species, Mol. Ecol. 6 (1997) 1189-1194.

[43] Varela M.C., Valdiviesso T., Phenological phases of Quercus suber L. flowering, For. Genet. 3 (1995) 93-102.

[44] Waits L.P., Liukart G., Taberlet P., Estimating the probability of identity among genotypes in natural populations: cautions and guidelines, Mol. Ecol. 10 (2001) 249-256.

[45] Zanetto A., Kremer A., Müller-Stark G., Hattemer H.H., Inheritance of isozymes in pedunculate oak (Quercus robur L.), J. Hered. 87 (1996) 364-370.

[46] Ziekiewicz E., Rafalski A., Labuda D., Genome fingerprinting by simple sequence repeat (SSR)-anchored polymerase chain reaction amplification, Genomics 20 (1994) 176-183. 